\title{
PENGARUH KEPEMIMPINAN TRANSFORMASIONAL KEPALA SEKOLAH, MORAL KERJA GURU, DAN KEPUASAN KERJA TERHADAP KINERJA GURU SDN DI KOTA MERAUKE
}

\author{
Basilius Redan Werang \\ Universitas Musamus Merauke Papua \\ email: lirang267@yahoo.co.id
}

\begin{abstract}
Abstrak: Penelitian penelitian ini bertujuan untuk menemukan ada tidaknya pengaruh kepemimpinan transformasional kepala sekolah, moral kerja guru, dan kepuasan kerja guru terhadap kinerja guru. Populasi penelitian meliputi 81orang guru sekolah dasar negeri di Kota Merauke. Tabel Krecjie digunakan sebagai pedoman untuk memilih sampel, yakni 69 orang guru, atau 85,19\% populasi. Data penelitian yang terkait dengan variabel kepemimpinan transformasional kepala sekolah, moral kerja guru, kepuasan kerja guru, dan kinerja guru dijaring dengan menggunakan instrumen yang berupa kuesioner. Selajutnya, data dianalisis menggunakan path analysis dengan bantuan program komputer SPSS for Windows Release 15. Hasil analisis data menunjukkan bahwa keterampilan manajerial kepala sekolah, moral kerja guru, dan kepuasan kerja guru berpengaruh secara positif dan signifikan terhadap kinerja guru.
\end{abstract}

Kata Kunci: kepemimpinan transformasional kepala sekolah, guru, kepuasan kerja guru, kinerja guru, moral kerja

\section{THE INFLUENCE OF SCHOOL PRINCIPALS' TRANSFORMATIONAL LEADERSHIP, TEACHERS' WORK MORALE, AND TEACHERS' WORK SATISFACTION ON TEACHERS' WORK PERFORMANCE AT STATE PRIMARY SCHOOLS IN THE CITY OF MERAUKE}

\begin{abstract}
This research was aimed at finding out whether there was an influence of principals' transformational leadership, teachers' work morale, and teachers' work satisfaction on teachers' work performance. The population included 81 teachers at State Primary Schools in Merauke city. Krecjie table was used to select the sample, that is, 69 teachers, $85,19 \%$ of the population. The data related to the research variables of principals' leadership, teachers' work morale, work satisfaction, and work performance were obtained by using questionnaires. The data were then analyzed using the path analysis with the aid of the computer program of SPSS for Windows Release 15. The findings indicated that there was a positive and significant influence of the principals' managerial skills, the teachers' work morale, and the teachers' work satisfaction on the teachers' work performance.
\end{abstract}

Keywords: $\quad$ school principals' transformational leadership, teachers' work morale, teachers' work satisfaction, teachers' work performance

\section{PENDAHULUAN}

Produktivitas suatu organisasi, tidak terkecuali sekolah ditentukan oleh kinerja para anggotanya. As'ad (1998:22) mengartikan kinerja sebagai hasil yang dicapai seseorang menurut ukuran yang berlaku untuk pekerjaan yang bersangkutan. Di pihak lain, Bernardin \& Russel (1993) mengartikan kinerja sebagai hasil yang dicapai oleh fungsi dan jabatan tertentu dalam periode waktu tertentu: "Performance is defined as the record of outcomes produced on a spe- cified job function or activity during a specified time period". Jadi, kinerja didefinisikan sebagai catatan tentang keluaran yang dihasilkan oleh fungsi pekerjaan atau aktivitas tertentu yang dilaksanakan dalam periode waktu tertentu.

Kinerja guru di sekolah (kelas) merujuk kepada perilaku guru dalam melaksanakan pekerjaan keguruan, yaitu mengajar. Gaynor (1998:46) menegaskan sebagai berikut. "Performance relates to what teachers do in the classroom and how that affects student learn- 
ing”. Kinerja bertalian erat dengan apa yang guru lakukan di dalam kelas dan bagaimana hal itu berpengaruh terhadap kegiatan belajar siswa. Berdasarkan pandangan ini, yang dimaksud dengan kinerja guru adalah perilaku yang terkait dengan aktivitas mengajar yang dijalankan oleh seorang guru di dalam kelas. Kesungguhan dan kontribusi maksimal guru-guru di dalam melaksanakan tugas akan terlihat dengan sangat jelas pada prestasi belajar para siswa.

Hal tersebut merupakan indikator untuk menentukan tingkat pencapaian hasil nyata antara rencana dan realisasi program kerja sekolah (Hersey \& Blanchard, 1992). Supaya kondisi kerja guru dapat terwujud seperti yang diharapkan, diperlukan seorang kepala sekolah yang tangguh dan memiliki visi yang jelas tentang tujuan semua kegiatan yang dilaksanakan di sekolah. Apabila kepala sekolah menjalankan tugas kepemimpinan secara efektif, guru akan merasa terdorong memberikan kontribusi nyata dalam usaha merealisasikan visi dan misi sekolah (Gibson, Ivancevich, dan Donnely, 1992).

Berdasarkan temuan di lapangan, peneliti meyakini ada beberapa faktor yang menentukan kualitas kinerja para guru Sekolah Dasar (SD) Negeri di Kota Merauke. Faktor pertama yang diyakini berpengaruh terhadap kualitas kinerja para guru adalah kepemimpinan kepala sekolah dengan titik pandang kepemimpinan transformasional kepala sekolah.

Sehubungan dengan upaya peningkatan kinerja guru dan mutu lulusan, kepala sekolah profesional akan memperhatikan beberapa hal seperti yang disarankan oleh Sallies (Mulyasa, 2006) berikut. (1) Memiliki visi yang kuat atau daya pandang yang mendalam tentang mutu yang terpadu bagi lembaganya maupun bagi tenaga kependidikan dan peserta didik yang ada di sekolah. (2) Memiliki komitmen yang jelas pada proses peningkatan kualitas tenaga kependidikan. (3) Mengkomunikasikan pesan yang berkaitan dengan kualitas pendidikan. (4) Menjamin kebutuhan peserta didik sebagai perhatian kegiatan dan kebijakan sekolah. (5) Meyakinkan para pelanggan (peserta didik, orang tua dan masyarakat) bahwa ada 'channel' yang cocok untuk menyampaikan berbagai harapan dan keinginannya. (6) Mendukung pengembangan tenaga kependidikan. (7) Tidak menyalahkan pihak lain jika ada masalah yang muncul tanpa dilandasi oleh bukti yang kuat. (8) Melakukan inovasi terhadap sekolah. (9) Menjamin struktur organisasi yang menggambarkan adanya tanggung jawab yang jelas. (10) Mengembangkan komitmen untuk menghilangkan setiap penghalang, baik yang bercorak organisasional maupun budaya. (11) Membangun tim kerja yang efektif. (12) Mengembangkan mekanisme yang cocok untuk monitoting dan evaluasi.

Besarnya pengaruh yang dimiliki oleh kepala sekolah menentukan apa dan bagaimana suatu pekerjaan dilaksanakan dalam sekolah yang dipimpin. Hal ini sejalan dengan pandangan Mantja (2002) yang mengatakan bahwa kepemimpinan kepala sekolah yang memberikan perhatian tinggi kepada guru, terbuka, menyejukkan, bisa beradaptasi dengan guru, murah senyum, simpatik, penuh pengertian, dan percaya bahwa para guru mampu melaksanakan tugas-tugas yang diembankan dan akan membuat mereka mengerjakan tugas itu dengan gembira dan penuh tanggung jawab.

Faktor lain yang diyakini berpengaruh terhadap kualitas kinerja guru SD Negeri (kasus di Kota Merauke) adalah kepuasan kerja guru. Arif (1986) mengemukakan bahwa kepuasan kerja adalah kondisi kerja yang dapat menciptakan tingkat motivasi yang tinggi dan dapat meningkatkan semangat kerja para pekerja untuk dapat melaksanakan tugas secara maksimal sehingga hasilnya terus meningkat. Di pihak lain, Fieldman \& Arnold (1983) mengemukakan bahwa kepuasan kerja merupakan keseluruhan sikap positif seseorang terhadap pekerjaannya. Sergiovani (1987) mengemukakan bahwa kepuasan kerja merupakan pernyataan akhir yang dihasilkan dari beberapa kejadian kerja dan yang berkaitan dengan kepentingannya.

Penelitian para ahli tentang kepuasan kerja menghasilkan pendapat yang beragam. Namun, penelitian tentang kepuasan kerja yang besar sumbangannya adalah penelitian yang dilakukan oleh Herzberg (1959). Herzberg (1959) menyebutkan beberapa faktor yang, menurutnya dapat mempengaruhi kepuasan dan ketidak- 
puasan kerja. Faktor-faktor ini dikelompokkannya ke dalam dua golongan teori yang disebut teori dua faktor, yaitu faktor pendorong (motivator factors) dan faktor penyehat (hygiene factors).

Kategori faktor pendorong (motivator factors) terdiri atas: (1) prestasi kerja atau achievement; (2) pengakuan atau recognition; (3) pekerjaan itu sendiri atau work itself; (4) tanggung jawab atau responsibility; dan 5) promosi jabatan atau advancement. Kategori faktor penyehat (hygiene factors) terdiri atas: (1) gaji; (2) peluang untuk tumbuh; (3) hubungan dengan bawahan; (4) hubungan antarpribadi rekan sejawat; (5) hubungan dengan atasan; (6) supervisi teknis; (7) kebijakan dan administrasi; (8) kedudukan/status; (9) kondisi kerja; (10) kehidupan pribadi; dan (11) keamanan kerja.

Pandangan Herzberg tentang kepuasan kerja dan ketidakpuasan kerja tidak merupakan satu garis kontinum, melainkan dua garis kontinum. Artinya, sumber-sumber kepuasan kerja tidak sama dengan sumber-sumber ketidakpuasan kerja. Pada kelompok pertama (motivator factors), ditemukan bahwa semakin terpenuhinya faktor-faktor kepuasan kerja seseorang, semakin puaslah orang itu. Demikian sebaliknya, semakin tidak terpenuhinya faktor-faktor kepuasan kerja seseorang, maka semakin menurun tingkat kepuasan orang itu. Pada kelompok kedua (hygiene factors), apabila faktor-faktor ketidakpuasan kerja berkurang, maka semakin puaslah orang itu. Tetapi sebaliknya, jika faktor-faktor ketidakpuasan semakin bertambah, maka semakin bertambah pula ketidakpuasan orang itu.

Wood, dkk. (Maupula, 2010) mengemukakan bahwa kepuasan kerja berhubungan erat dengan adanya rasa percaya dan perasaan positif terhadap karakteristik pekerjaan dan pengalaman-pengalaman kerja. Kepuasan kerja sesungguhnya dikembangkan oleh setiap pekerja atas dasar pekerjaan yang menantang, kondisi pekerjaan yang bagus, imbalan yang berkeadilan, dan peluang untuk promosi jabatan atau peningkatan karier. Kepuasan kerja dapat mengurangi tingkat kemangkiran dan atau perpindahan kerja, walaupun hal tersebut tidak serta-mer- ta dapat meningkatkan kinerja.

Faktor lain yang juga diyakini turut memengaruhi kualitas kinerja guru adalah moral kerja guru. Kata 'moral' yang dimaksudkan di dalam penelitian ini lebih merujuk kepada kata bahasa Inggris morale yang berarti semangat juang. Lucio dan McNeil (1979) mengartikan moral sebagai sikap dan perilaku yang menunjukkan sebuah kemauan untuk terlibat di dalam sekolah dan pekerjaannya. Di pihak lain, Lucio dan McNeil (Bafadal (2006) memaknai moral sebagai sikap dan tingkah-laku yang merupakan perwujudan suatu kemauan yang dibawa serta ke sekolah dan kerjanya. Bafadal (2006) menegaskan bahwa moral kerja merupakan perwujudan kemauan seseorang melalui sikap dan tingkah lakunya. Adanya perbedaan kemauan akan menyebabkan terjadinya pula perbedaan pada sikap dan tingkah-laku seseorang.

Moral kerja guru dapat sangat berpengaruh terhadap kelangsungan seluruh proses pembelajaran di dalam kelas, dan pada akhirnya akan memengaruhi pula kualitas lulusan. Seorang guru yang memiliki moral kerja yang tinggi sangat besar berpotensi menghasilkan sesuatu yang lebih banyak dan lebih baik. Guru yang memiliki moral kerja tinggi akan bekerja dengan penuh antusias, penuh gairah, penuh inisiatif, penuh kegembiraan, tenang, teliti, suka bekerja sama dengan orang lain, ulet, tabah, dan tidak pernah datang terlambat. Guru yang memiliki moral kerja rendah akan kurang bergairah dalam bekerja, malas, sering melamun, sering terlambat atau tidak masuk kerja, sering mengganggu, selalu menyendiri, dan sering melakukan kesalahan di dalam melaksanakan tugas (Bafadal, 2006).

\section{METODE}

Pendekatan yang digunakan dalam penelitian ini adalah kuantitatif dengan rancangan penelitian korelasional. Rancangan penelitian korelasional dimaksudkan untuk menjelaskan apakah ada pengaruh antara variabel-variabel yang diteliti berdasarkan besar kecilnya koefisien korelasi (Kachigan, 1982).

Secara konseptual, model hubungan antarvariabel dapat dilihat pada Gambar 1. 


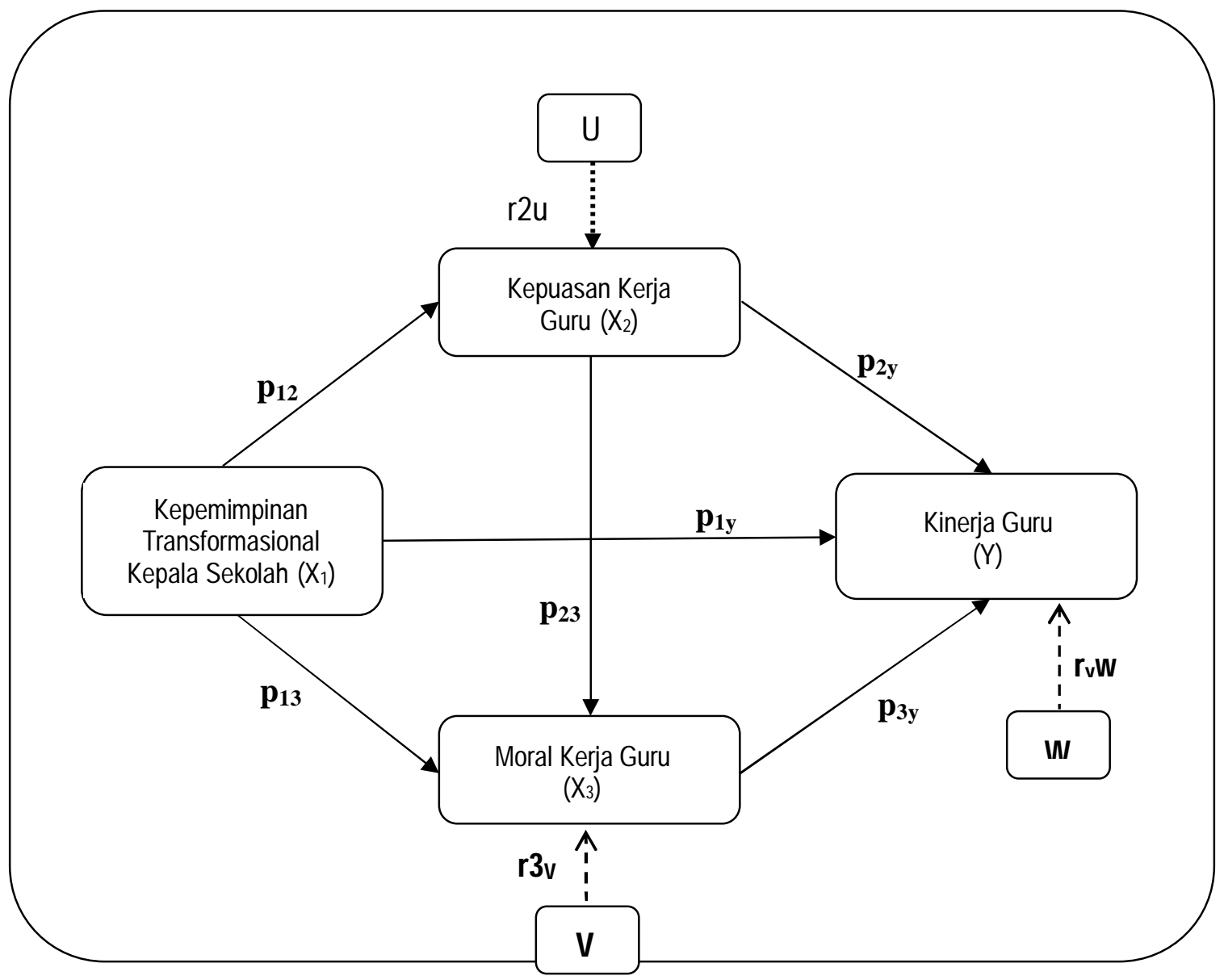

Gambar 1. Model Konseptual Hubungan antarvariabel Penelitian

Keterangan:

$\mathrm{Y}$

$\mathrm{X} 1$

$\mathrm{X} 2$

$\mathrm{X} 3$

$\mathrm{p} 12$

p13

p23

p1y

$\mathrm{p} 2 \mathrm{y}$

py3

r2u, r3v, ryw

$\mathrm{U}, \mathrm{V}, \mathrm{W}$
: Kinerja guru

: Kepemimpinan transformasional kepala sekolah

: Moral kerja guru

: Kepuasan kerja guru

: Koefisien pengaruh antara $X_{1}$ dan $X_{2}$

: Koefisien pengaruh antara $X_{1}$ dan $X_{3}$

: Koefisien pengaruh antara $X_{2}$ dan $X_{3}$

: Koefisien pengaruh antara $\mathrm{X}_{1}$ dan $\mathrm{Y}$

: Koefisien pengaruh antara $X_{2}$ dan $Y$

: Koefisien pengaruh antara $\mathrm{X}_{3}$ dan $\mathrm{Y}$

: Koefisien residual

: Residual
Populasi penelitian ini adalah semua guru SD Negeri di Kota Merauke yang berjumlah 81 orang. Untuk mendapatkan jumlah sampel yang memadai, dipergunakan Tabel Krecjie. Berdasarkan Tabel Krecjie, apabila populasinya berjumlah sekitar 80-85 orang, jumlah sampel akan berkisar antara 66 dan 70 orang. Penelitian ini memiliki populasi sebesar 81 orang. Oleh karena itu, dalam penelitian ini ditetapkan jumlah sampel sebanyak 69 orang.

Data penelitian dihimpun melalui penyebaran angket yang berisi sejumlah pernyataan yang berkaitan dengan variabel-variabel yang diteliti, yaitu: 10 pernyataan berkaitan dengan 
variabel kepemimpinan transformasional kepala sekolah, 15 pernyataan berkaitan dengan variabel kepuasan kerja guru, 17 pernyataan berkaitan dengan variabel moral kerja guru, dan 29 pernyataan berkaitan dengan variabel kinerja guru. Angket disebarkan kepada guru-guru yang telah ditetapkan sebagai responden. Data yang terkumpul kemudian dianalisis dengan menggunakan teknik analisis jalur. Analisis data penelitian dilakukan dengan bantuan komputer program SPSS for Windows Release 15.

\section{HASIL DAN PEMBAHASAN Hasil}

Berdasarkan hasil analisis jalur yang dilakukan diperoleh informasi sebagai berikut.

Nilai $p_{12}$ yang merupakan koefisien pengaruh langsung kepemimpinan transformasional kepala sekolah (X1) terhadap kepuasan kerja guru (X3) SD Negeri di Kota Merauke yang digambarkan dengan nilai koefisien determinasi $\left(\mathrm{R}^{2)}\right.$ sebesar 0,3147 . Artinya, variabel kepemimpinan transformasional kepala sekolah $\left(\mathrm{X}_{1}\right)$ berpengaruh terhadap kepuasan kerja guru $\left(\mathrm{X}_{2}\right)$ sebesar $31,47 \%$. Dengan kata lain, kepuasan kerja guru $\left(\mathrm{X}_{2}\right)$ dipengaruhi oleh faktor kepemimpinan transformasional kepala sekolah $\left(X_{1}\right)$ sebesar $31,47 \%$. Sisanya, $68,53 \%$ dijelaskan oleh variabel lain selain kepemimpinan transformasional kepala sekolah $\left(\mathrm{X}_{1}\right)$ atau variabel yang tidak terdapat dalam model regresi ini. Berpijak pada data hasil analisis ini, dapat dikatakan bahwa pada taraf signifikansi 0,05 atau taraf kepercayaan $95 \%$, antara variabel bebas (kepemimpinan transformasional kepala sekolah) dan variabel terikat (kepuasan kerja guru) terdapat pengaruh yang signifikan. Hal tersebut berarti hipotesis penelitian yang mengatakan "Ada pengaruh langsung yang signifikan kepemimpinan transformasional kepala sekolah terhadap kepuasan kerja guru SD Negeri di Kota Merauke" diterima.

Nilai $\mathrm{p}_{13}$ yang merupakan koefisien pengaruh langsung kepemimpinan transformasional kepala sekolah $\left(\mathrm{X}_{1}\right)$ terhadap moral kerja guru $\left(\mathrm{X}_{3}\right)$ SD Negeri di Kota Merauke yang digambarkan nilai koefisien determinasi $\left(\mathrm{R}^{2)}\right.$ sebesar 0,1664. Artinya, variabel kepemimpin- an transformasional kepala sekolah $\left(\mathrm{X}_{1}\right)$ berpengaruh terhadap moral kerja guru $\left(\mathrm{X}_{3}\right)$ sebesar $16,64 \%$. Dengan kata lain, moral kerja guru $\left(\mathrm{X}_{3}\right)$ dipengaruhi oleh faktor kepemimpinan transformasional kepala sekolah $\left(\mathrm{X}_{1}\right)$ sebesar $16,64 \%$. Sisanya, sebesar $83,36 \%$ dijelaskan oleh variabel lain selain kepemimpinan transformasional kepala sekolah $\left(\mathrm{X}_{1}\right)$ atau variabel yang tidak terdapat dalam model regresi ini. Berpijak pada data hasil analisis tersebut, dapat dikatakan bahwa pada taraf signifikansi 0,05 atau taraf kepercayaan $95 \%$, antara variabel kepemimpinan transformasional kepala sekolah dan variabel moral kerja guru terdapat pengaruh langsung yang signifikan. Hal itu berarti hipotesis penelitian yang mengatakan "Ada pengaruh langsung yang signifikan kepemimpinan transformasional kepala sekolah terhadap moral kerja guru SD Negeri di Kota Merauke" diterima.

Nilai $\mathrm{p}_{1 \mathrm{y}}$ yang merupakan koefisien pengaruh langsung kepemimpinan transformasional kepala sekolah (X1) dengan kinerja guru (Y) SD Negeri di Kota Merauke yang digambarkan dengan nilai koefisien determinasi $\left(\mathrm{R}^{2)}\right.$ sebesar 0,1069. Artinya, variabel kepemimpinan transformasional kepala sekolah $\left(\mathrm{X}_{1}\right)$ berpengaruh terhadap kinerja guru $(\mathrm{Y})$ sebesar $10,69 \%$. Dengan kata lain, kinerja guru $(\mathrm{Y})$ dipengaruhi oleh faktor kepemimpinan transformasional kepala sekolah $\left(\mathrm{X}_{1}\right)$ sebesar $10,69 \%$. Sisanya, $89,31 \%$ dijelaskan oleh variabel lain selain kepemimpinan transformasional kepala sekolah $\left(\mathrm{X}_{1}\right)$ atau variabel yang tidak terdapat dalam model regresi ini. Berpijak pada data hasil analisis tersebut, dapat dikatakan bahwa pada taraf signifikansi 0,05 atau taraf kepercayaan 95\%, antara variabel bebas (kepemimpinan transformasional kepala sekolah) dan variabel terikat (kinerja guru) terdapat pengaruh yang signifikan. Hal tersebut berarti hipotesis penelitian yang mengatakan "Ada pengaruh langsung yang signifikan kepemimpinan transformasional kepala sekolah terhadap kinerja guru SD Negeri di Kota Merauke" diterima.

Nilai $\mathrm{p}_{23}$ yang merupakan koefisien pengaruh langsung kepuasan kerja guru $\left(\mathrm{X}_{2}\right)$ dengan moral kerja guru $\left(\mathrm{X}_{3}\right)$ SD Negeri di Kota 
Merauke yang digambarkan dengan nilai koefisien deternimanasi determinasi $\left(\mathrm{R}^{2}\right)$ sebesar 0,2480. Artinya, variabel kepuasan kerja guru $\left(\mathrm{X}_{2}\right)$ berpengaruh signifikan terhadap moral kerja guru $\left(X_{3}\right)$ sebesar $24,80 \%$. Dengan kata lain, moral kerja guru $\left(\mathrm{X}_{3}\right)$ dipengaruhi oleh faktor kepuasan kerja guru $\left(\mathrm{X}_{2}\right)$ sebesar $24,80 \%$. Sisanya, 75,20\% dijelaskan oleh variabel lain selain kepuasan kerja guru $\left(\mathrm{X}_{2}\right)$ atau variabel yang tidak terdapat dalam model regresi ini. Hal tersebut berarti variabel kepuasan kerja guru berpengaruh positif dan signifikan terhadap moral kerja guru SD Negeri di kota Merauke. Dengan demikian, hipotesis kerja yang berbunyi: "Terdapat pengaruh langsung yang signifikan kepuasan kerja guru terhadap moral kerja guru SD Negeri di kota Merauke" diterima.

Nilai $\mathrm{p}_{2 y}$ yang merupakan koefisien pengaruh langsung kepuasan kerja guru $\left(\mathrm{X}_{2}\right)$ terhadap kinerja guru (Y) SD Negeri di Kota Merauke yang digambarkan dengan nilai koefisien determinasi determinasi $\left(\mathrm{R}^{2}\right)$ sebesar 0,2162. Artinya, variabel kepuasan kerja guru $\left(\mathrm{X}_{2}\right)$ berpengaruh signifikan terhadap kinerja guru (Y) sebesar 21,62\%. Dengan kata lain, kinerja guru (Y) dipengaruhi oleh faktor kepuasan kerja guru $\left(\mathrm{X}_{2}\right)$ sebesar $21,62 \%$. Sisanya, $68,38 \%$ dijelaskan oleh variabel lain selain kepuasan kerja guru $\left(\mathrm{X}_{2}\right)$ atau variabel yang tidak terdapat dalam model regresi ini. Hal tersebut berarti variabel kepuasan kerja guru berpengaruh positif dan signifikan terhadap kinerja guru SD Negeri di kota Merauke. Dengan demikian, hipotesis kerja yang berbunyi: "Terdapat pengaruh langsung yang signifikan kepuasan kerja guru terhadap kinerja guru SD Negeri di kota Merauke" diterima.

Nilai $p_{3 y}$ yang merupakan koefisien pengaruh langsung moral kerja guru $\left(\mathrm{X}_{3}\right)$ terhadap kinerja guru (Y) SD Negeri di Kota Merauke yang digambarkan dengan nilai koefisien determinasi $\left(\mathrm{R}^{2)}\right.$ sebesar 0,0542. Artinya, variabel moral kerja guru $\left(\mathrm{X}_{3}\right)$ berpengaruh terhadap kinerja guru (Y) sebesar 5,42\%. Dengan kata lain, kinerja guru (Y) dipengaruhi oleh faktor moral kerja guru $\left(\mathrm{X}_{3}\right)$ sebesar $5,42 \%$. Sisanya, $94,58 \%$ dijelaskan oleh variabel lain selain mo- ral kerja guru $\left(\mathrm{X}_{3}\right)$ atau variabel yang tidak terdapat dalam model regresi ini. Berpijak pada data hasil analisis ini dapat dikatakan bahwa pada taraf signifikansi 0,05 atau taraf kepercayaan $95 \%$, antara variabel bebas (moral kerja guru) dan variabel terikat (kinerja guru) terdapat pengaruh yang signifikan. Hal tersebut berarti hipotesis penelitian yang mengatakan: "Terdapat pengaruh langsung yang signifikan moral kerja guru dengan kinerja guru SD Negeri di Kota Merauke" diterima.

Koefisien residual variabel terikat untuk setiap jalur hubungan blok sebagai berikut

Koefisien jalur hubungan untuk residual r2u adalah:

$$
\mathrm{r} 2 \mathrm{u}=\sqrt{ }(1-0,3147 \overline{=0,828}
$$

Koefisien jalur hubungan untuk residual r3v adalah:

$$
\mathrm{r} 3 \mathrm{v}=\sqrt{ }(1-0,641) \overline{=0,599}
$$

Koefisien jalur hubungan untuk residual ryw adalah:

$$
\text { ryw }=\sqrt{(1-0,808)} \overline{=0,438}
$$

Model empirik hubungan antarvariabel penelitian dapat dilihat dalam Gambar 2.

\section{Pembahasan}

Berdasarkan hasil analisis ditemukan bahwa kepemimpinan transfornasional kepala sekolah berpengaruh secara signifikan terhadap kepuasan kerja guru SD Negeri di Kota Merauke. Hal ini berarti bahwa semakin tinggi tingkat kepemimpinan transformasional kepala sekolah akan diikuti oleh semakin meningkatnya kepuasan kerja guru. Temuan penelitian ini sejalan dengan hasil penelitian Tuapattinaja dan Werang (2011) yang menyimpulkan adanya hubungan yang positif dan signifikan antara kepemimpinan transformasional Kepala Distrik dengan kepuasan kerja pegawai kantor Distrik Merauke dan Distrik Sota. Temuan penelitian ini juga sejalan dengan hasil penelitian Agung (2009) yang menyimpulkan adanya hubungan langsung yang signifikan antara kepemimpinan transformasional dan kepuasan kerja. 


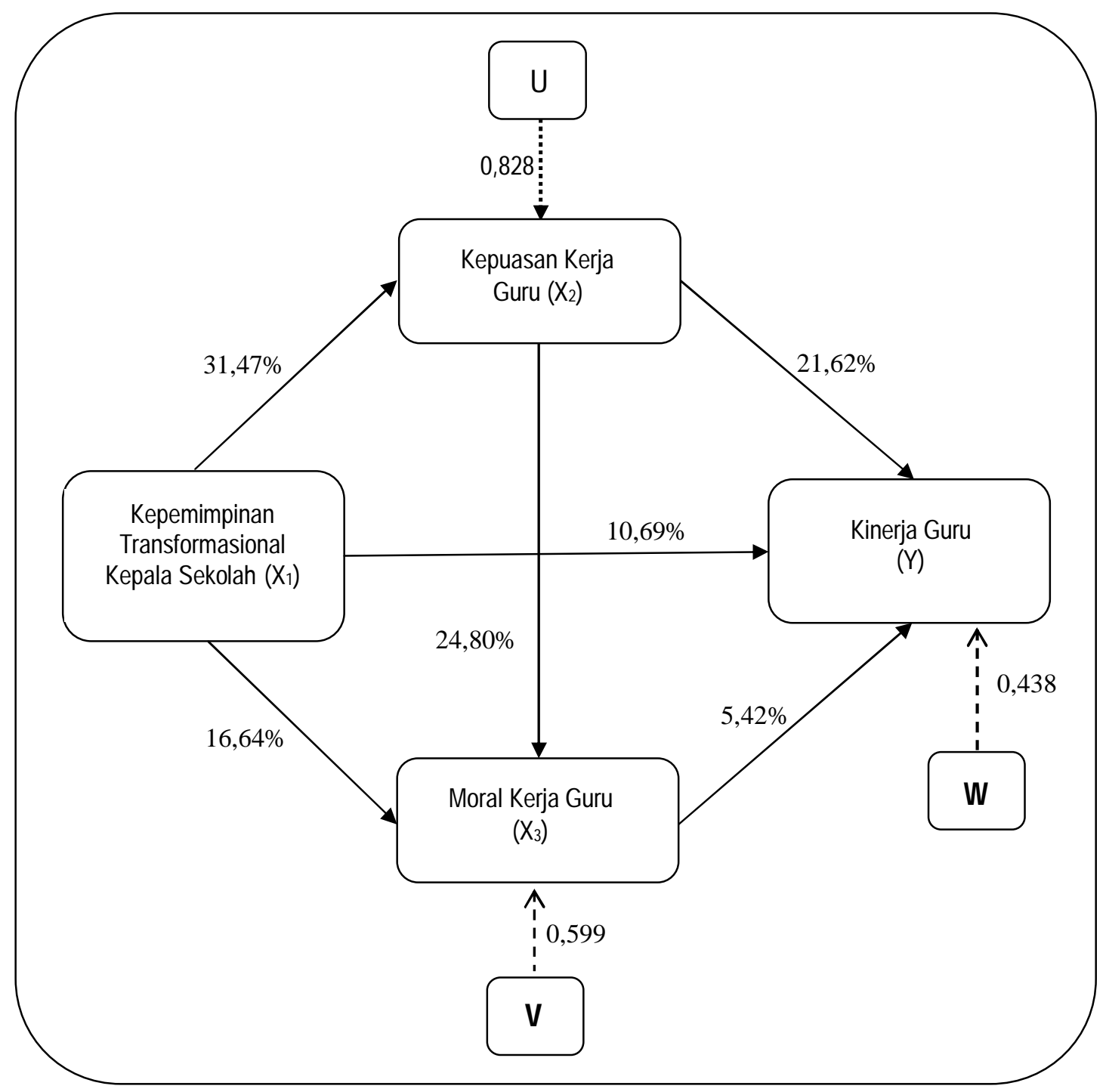

Gambar 2. Model Empirik Hubungan antarvariabel Penelitian

Hasil analisis data juga menunjukkan bahwa kepemimpinan transformasional kepala sekolah berpengaruh secara signifikan terhadap moral kerja guru SD Negeri di Kota Merauke. Hasil analisis ini mengindikasikan bahwa semakin meningkatnya kepemimpinan transformasional kepala sekolah akan segera diikuti oleh semakin meningkatnya moral kerja guru SD Negeri di Kota Merauke. Sebagaimana dikemukakan oleh Mantja (2002), kepala sekolah adalah sumber semangat bagi guru-guru dan siswa. Kepala sekolah yang terbuka, suka mendengarkan dan bersahabat dengan guru-guru akan membuat guru-guru dapat bekerja dengan lebih tenang dan senang. Temuan penelitian ini sejalan dengan hasil analisis Nawawi (1989) yang mengatakan bahwa hubungan yang penuh kekeluargaan terlepas dari formalitas yang kaku dan prosedural yang otokratis berpengaruh positif terhadap moral kerja guru. Temuan penelitian ini juga senada dengan hasil penelitian Masyhud \& Tasnim (2002) dan Iwantoro (2006) yang mengungkapkan adanya pengaruh kepemimpinan kepala sekolah terhadap semangat kerja guru.

Berdasarkan hasil analisis data ditemukan bahwa kepemimpinan transformasional kepala sekolah berpengaruh secara signifikan terhadap kinerja guru SD Negeri di kota Merauke. Artinya, semakin meningkatnya kepemimpinan transformasional kepala sekolah akan diikuti oleh semakin meningkatnya kinerja para guru SD Negeri di Kota Merauke. Kepala sekolah yang profesional akan menemani dan meng- 
awasi penampilan guru dan anak didiknya di sekolah (di kelas), memberikan masukan yang positif dan konstruktif untuk perbaikan dan pengembangan sistem dan metode pembelajaran, mendorong pemanfaatan waktu dan fasilitas belajar secara efektif dan kreatif (Scheerens \& Bosker, 1997).

Temuan penelitian ini sejalan dengan hasil penelitian Collinson (1993) yang menyimpulkan bahwa manajemen yang baik berpengaruh terhadap kinerja guru di sekolah. Pentingnya pengaruh kepemimpinan transformasional kepala sekolah terhadap kinerja guru diungkapkan juga oleh Collin, Dennis, dan Owen (Meggan dkk., 2005). Dalam hasil penelitiannya, mereka menyimpulkan bahwa kepemimpinan transformasional kepala sekolah berpengaruh positif terhadap kinerja guru. Temuan penelitian ini sejalan dengan hasil penelitian Setiawati (2011) yang menyimpulkan adanya pengaruh positif yang signifikan antara kepemimpinan transformasional terhadap kinerja karyawan PT PLN (Persero) Distribusi Jawa Timur APJ Malang.

Hasil analisis data juga menunjukkan bahwa kepuasan kerja guru berpengaruh secara signifikan terhadap moral kerja guru SD Negeri di Kota Merauke. Artinya, semakin tinggi tingkat kepuasan kerja guru akan diikuti oleh semakin meningkatnya semangat kerja guru SD Negeri di Kota Merauke. Temuan penelitian ini sejalan dengan padangan Herzberg (1969) mengatakan bahwa salah satu faktor yang dapat meningkatkan semangat kerja adalah kepuasan kerja (job satisfaction). Temuan penelitian ini sejalan juga dengan hasil penelitian Puji (2009) yang menyimpulkan bahwa kepuasan kerja berpengaruh secara signifikan terhadap semangat kerja karyawan produksi PT Surya Sakti Utama Surabaya. Temuan penelitian ini juga sejalan dengan hasil penelitian Febrianto (2010) yang menyimpulkan bahwa kepuasan kerja berpengaruh secara signifikan terhadap semangat kerja karyawan PT Ricky Jaya Sakti Surabaya.

Hasil analisis data juga menunjukkan bahwa kepuasan kerja guru berpengaruh secara signifikan terhadap kinerja guru. Hal ini berarti bahwa semakin tinggi tingkat kepuasan kerja guru akan diikuti oleh semakin meningkatnya kinerja guru SD Negeri di Kota Merauke. Hasil penelitian ini sejalan dengan hasil penelitian Tuapattinaja dan Werang (2011) yang menyimpulkan adanya hubungan yang signifikan antara kepuasan kerja pegawai dengan kinerja pegawai kantor Distrik Merauke dan Distrik Sota. Temuan penelitian ini sejalan juga dengan hasil penelitian Yuliejantiningsih (2005) dan Maupula (2010) yang mengungkapkan adanya hubungan yang signifikan antara kepuasan kerja guru dengan kinerja guru.

Berdasarkan hasil analisis data terungkap bahwa moral kerja guru berpengaruh secara signifikan terhadap kinerja guru. Hasil analisis ini menunjukkan bahwa meningkatnya moral kerja guru akan selalu diikuti oleh semakin meningkatnya kinerja guru SD Negeri di Kota Merauke. Guru-guru yang mampu menciptakan iklim belajar yang baik dan kondusif, selalu berusaha melibatkan para siswa dalam proses pembelajaran cenderung menguntungkan dalam upaya pencapaian tujuan pembelajaran. Temuan penelitian ini sejalan dengan hasil penelitian Mustika (2002) yang menyimpulkan bahwa terdapat hubungan langsung yang signifikan antara semangat kerja guru dengan kinerja guru. Temuan penelitian ini juga mendukung hasil analisis Nawawi (1985) yang mengungkapkan bahwa tinggi rendahnya moral kerja guru sangat berpengaruh kepada produktivitas kerja yang dicapai oleh guru tersebut di dalam proses pembelajaran.

\section{PENUTUP}

\section{Kesimpulan}

Berdasarkan hasil analisis data dan pembahasan hasil penelitian dapat dikemukakan kesimpulan sebagai berikut.

- Kepempimpinan transformasional kepala sekolah berpengaruh secara signifikan terhadap kepuasan kerja guru SD Negeri di Kota Merauke.

- Kepemimpinan transformasional kepala sekolah berpengaruh secara signifikan terhadap moral kerja guru SD Negeri di Kota Merauke.

- Kepemimpinan transformasional kepala se- 
kolah berpengaruh secara signifikan terhadap kinerja guru SD Negeri di Kota Merauke.

- Kepuasan kerja guru berpengaruh secara signifikan terhadap moral kerja guru SD Negeri di Kota Merauke.

- Kepuasan kerja guru berpengaruh secara signifikan terhadap kinerja guru SD Negeri di Kota Merauke.

- Moral kerja guru berpengaruh secara signifikan terhadap kinerja guru SD Negeri di Kota Merauke.

\section{Saran}

Berdasarkan kesimpulan di atas, terdapat dua saran yang dapat dikemukakan. Pertama, kepala sekolah hendaknya direkrut dan diseleksi dari para guru yang tidak hanya memiliki pangkat/golongan yang tinggi, tetapi juga memiliki kualitas pribadi dan kinerja yang tinggi. Kedua, para kepala sekolah dan calon kepala sekolah diberikan pendidikan dan pelatihan yang cukup guna mengemban tugas pembinaan dan pengembangan sekolah yang diembankan kepadanya. Tidak adanya pendidikan dan pelatihan yang khusus bagi para kepala sekolah terpilih akan berdampak kepada amburadulnya pengelolaan sekolah, yang pada akhirnya bermuara kepada meningkatnya ketidakpuasan guru, serta menurunnya semangat dan kinerja guru.

\section{UCAPAN TERIMA KASIH}

Ucapan terima kasih disampaikan kepada pihak sponsor yang telah mendanai penelitian ini, para narasumber, responden, dan sahabat yang membantu pelaksanaan penelitian. $\mathrm{Mu}-$ dah-mudahan penelitian ini ada manfaatnya.

\section{DAFTAR PUSTAKA}

Agung, A. A. G. 2009. "Hubungan Kepemimpinan Transformasional, Kelelahan Emosional, Karakteristik Individu, Budaya Organisasi dan Kepuasan Kerja dengan Komitmen Organisasional pada Guru SMA di Kota Denpasar". Disertasi, Tidak Dipublikasikan. Malang: PPS Universitas Negeri Malang.
Arif, M. S. 1986. Organisasi dan Manajemen. Jakarta: Karunika dan Universitas Terbuka.

As'ad, M. 1998. Psikologi Industri: Seri Ilmu Sumber Daya Manusia. Edisi Keempat. Yogyakarta: Liberty.

Bafadal, I. 2006. Peningkatan Profesionalisme Guru Sekolah Dasar. Jakarta: Bumi Aksara.

Bernardin, J.H. \& Russel, J.E. A 1993. Human Resource Management. Singapore: Mc Graw-Hill, Inc.

Collinsen, V. 1993. "Redefining Teacher Excellence: Theory into Practice". Journal. Vol 38 (9), p. 23.

Febrianto, A. 2010. "Analisis Pengaruh Kepuasan Kerja dan Komitmen Organisasi Terhadap Semangat Kerja Karyawan Pada PT. Ricky Jaya Sakti Surabaya". Skripsi, Tidak Diterbitkan. Surabaya: Universitas Pembangunan Nasional Veteran.

Fieldman, D. C. \& Arnold, H. J. 1983. Managing Indidual and Group Behavior in Organization. Singapore: McGraw-Hill Book Company.

Gaynor, A.K. 1998. Analyzing Problems in Schools and Schools Systems: A Theoretical Approach. Hillsdale, NJ: Lawrence Erlbaum Associates.

Gibson, J. L.; Ivanzevich, J. M., \& Donelly, J. H. 1992. Organisasi: Perilaku, Struktur dan Proses. Jilid I. Alih Bahasa oleh Agus Dharma. Jakarta: Erlangga.

Hersey, P. dan Blanchard, K. H. 1992, Management of Organizational Behavior. Englewood Cliffs, New Jersey: Prentice-Hall Inc. 
Herzberg, F. 1959. Motivation to Work. Second Edition. New York: John Willey and Sons, Inc.

Iwantoro. 2006. "Kompetensi Kekepalsekolahan dalam Hubungannya dengan Semangat Kerja Guru SD Negeri di Kabupaten Mojokerto". Tesis Tidak Diterbitkan. Malang: PPS Universitas Negeri Malang.

Kachigan, S. K. 1982. Multivariate Statistical Analysis. New York: Radius Press.

Lucio, W.H. \& McNeil, J.D. 1979. Supervision in Thought and Action. New York: Mc Graw Hill Book Company.

Mantja, W. 2002. Manajemen Pendidikan dan Supervisi Pengajaran. Malang: Wineka Media.

Masyhud, M.S. \& Tasnim, Z. 2002. "Pengaruh Kepemimpinan Kepala Sekolah dan Iklim Organisasi Sekolah Terhadap Pelibatan Guru dalam Pengambilan Keputusan, Semangat Kerja Guru dan Kedisiplinan Siswa pada Sekolah Dasar di Wilayah Eks Keresidenan Besuki". Laporan Penelitian Dosen BBI. Jember: Lemlit Universitas Negeri Jember.

Maupula, P. 2010. "Hubungan antara Perilaku Kepemimpinan Kepala Sekolah, Iklim Organisasi Sekolah, Profesionalisme Guru dan Kepuasan Guru dengan Kinerja Guru SD Negeri di Kota Kupang". Disertasi, Tidak Dipublikasikan. Malang: PPS Universitas Negeri Malang.

Megan, C.; Leslie, K. \& Colin, R. 2005. Leadership and Teams in Educational Management. Alih Bahasa oleh D.W. Eric. Jakarta: Grasindo.

Mulyasa, E., 2006. Menjadi Kepala Sekolah Profesional. Bandung: Rosdakarya.
Kerja, Motivasi Kerja dan Semangat Kerja dengan Kinerja Guru SMK Swasta Kota Malang". Tesis, Tidak Diterbitkan. Malang: PPS Universitas Negeri Malang.

Nawawi, H. 1985. Organisasi Sekolah dan Pengelolaan Kelas. Jakarta: Gunung Agung.

Nawawi, H. 1989. Administrasi Pendidikan. Jakarta: Gunung Agung.

Puji, I. 2009. "Pengaruh Kepuasan Kerja terhadap Semangat Kerja Karyawan Bagian Produksi pada PT Surya Sakti Utama Surabaya". Skripsi, Tidak Diterbitkan. Surabaya: Universitas Airlangga.

Scheeren, J. \& Bosker, R. J. 1997. The Foundation of Education Effectiveness. Great Britain: Redwood Books Ltd.

Sergiovani, T. J. 1987. The Principalship. A Reflective Practice Perspective. Boston: Allyn and Bacon.

Setiawati, I. 2011. "Pengaruh Kepemimpinan Transformasional terhadap Kinerja melalui Motivasi Kerja [Studi pada Karyawan PT. PLN (Persero) Distribusi Jawa Timur APJ Malang]”. Skripsi. Malang: Universitas Negeri Malang.

Tuapattinaja, D. J. P. \& Werang, B. R. 2011. "Hubungan Kepemimpinan Transformasional Kepala Distrik dan Kepuasan Kerja Pegawai dengan Kinerja Pegawai Kantor Distrik Merauke dan Distrik Sota”. Laporan Penelitian. LP2M Universitas Musamus.

Yuliejantiningsih, Y. 2005. "Hubungan Iklim Sekolah, Beban Tugas, Motivasi Berprestasi, dan Kepuasan Kerja dengan Kinerja Guru SD Negeri di Kota Mojokerto". Disertasi. Tidak Diterbitkan. Malang: PPS UM.

Mustika, Z. 2002. "Hubungan antardisiplin 